\title{
DIYARI LANGUAGE POSTCARDS AND DIYARI LITERACY
}

\author{
Peter Austin
}

This paper is a study of eight postcards written in the Diyari language ${ }^{1}$ by Rebecca Maltilina and addressed to Miss Dorothea Ruediger. ${ }^{2}$ As Cane and Gunson argue (this volume), postcards are potentially an important record of Australian history and Australian Aboriginal biography. These postcards are of additional linguistic and socio-linguistic importance in that they represent literature written in an Aboriginal language by an Aboriginal person. They are also important because of what they reveal about the place of literacy and writing in the lives of Diyari speakers.

Diyari (or Dieri, as it is more commonly spelled) ${ }^{3}$ is an Australian Aboriginal language, traditionally spoken along Cooper Creek to the east of Lake Eyre in the far north of South Australia. ${ }^{4}$ There appear to have been at least five named local groups speaking Diyari. ${ }^{5}$ Currently there are two or three speakers of the language living in Marree and Port Augusta. Diyari is unusual among Australian languages in having a long and well-established tradition of vernacular literacy. 6 There is a large amount of material written in Diyari, both by Europeans (primarily translations of Christian religious texts) and by native speakers. There is an established orthography and most of this material is written in it.

Peter Austin is presently senior lecturer and Head of the Division of Linguistics, La Trobe University. He has carried out linguistic fieldwork in northern New South Wales, in northern South Australia and the north-west of Western Australia. His current research focus is the Western Australia languages for which he is preparing dictionaries, grammars and text collections.

1 I wish to thank Niel Gunson for providing photographs of the postcards and discussing them with me. My knowledge of Diyari is based on fieldwork carried out in 1974-77 while I was a postgraduate student at the Australian National University. I am grateful to my Diyari teachers for assisting me with learning their language. A reference grammar of the language has been published (Austin 1981). I am also grateful to the Australian Institute of Aboriginal Studies for providing a grant to undertake bibliographical research at the Lutheran Archives, Adelaide, in 1976, resulting in the opportunity to examine much of the Diyari literature produced by the Lutheran Mission. Bill McGregor and Charles Ferguson made a number of helpful comments on an earlier draft of this paper; remaining errors are my own.

2. Postcards 2, 3 and 4 were addressed to Miss 'Reidiger' at Killalpaninna via Hergott (later Marree), South Australia, while postcard 6 is addressed to Court House Hotel, Aberdeen, Burra SA and postcard 8 is addressed to Opies Hotel, Aberdeen, Burra SA. The other cards $(1,5$, and 7$)$ bear no address.

3 Phonemically the language name is Diyari, or in the mission spelling.Diari. The widely used spelling Dieri can be found in the writings of Flierl, Schoknecht, Howitt, Berndt and Tindale.

4 See maps 1, 2 in Austin 1981:3,7.

5 See Austin 1981:3-4.

6 See Ferguson 1987. Other Australian languages with similar traditions are Aranda, Guugu Yimidhirr and Mabuiag. 


\section{The Lutheran Mission Writings.}

In 1867 a Lutheran mission was established at Lake Killalpaninna ${ }^{7}$ (kirlawirlpanhinha), ${ }^{8}$ an important meeting place in the country of the kunarrhi Diyari, but the missionaries were forced to leave when the local Aborigines became hostile. The Lutherans returned in 1869 when a police station was established at Lake Kopperamanna (kaparrhamaranha) ${ }^{9}$ and began to minister to the Diyari and other Aboriginal groups who assembled on the mission station they set up. The missionaries immediately began to study the Diyari language and to develop an orthography for it. A school was set up and in 1870 an elementary primer for use in teaching was printed. ${ }^{10}$ It contains a list of symbols, syllables, words, sentences and short texts. Pastor Carl Schoknecht, who spent 1871 to 1873 at Killalpaninna, compiled a thirty seven page Diyari-German and German-Diyari vocabulary, ${ }^{11}$ together with a grammatical statement setting out the noun and verb inflections. The orthography used by Schoknecht is the same as that employed in the primer and has two notable features: ${ }^{12}$ the lamino-palatal stop is spelled $x$; and the initial velar nasal is consistently misrepresented, being either left out completely or written as one of the other nasals $m$ or $n$.

In 1878 Pastor John Flierl joined the mission and built up its operations. Flierl was an excellent linguist and soon reformed the spelling system, recognising the initial velar nasal (which he wrote $n g$ ) and substituting $t j$ for earlier $x$ to represent the lamino-palatal stop. He translated the catechism and the Epistles and Gospels into Diyari ${ }^{13}$ and refined Schoknecht's grammatical statement, adding a parallel grammar of Wangkanguru, the language spoken north-west of Diyari. The orthography developed by Flierl remained the standard for all mission writings (published and unpublished) until the mission closed in 1915. The same orthography was employed by Reuther and Strehlow in their Diyari translation of the New Testament ${ }^{14}$ and by Reuther in his monumental thirteen-volume ethnographic and linguistic notes, including a four-volume dictionary. ${ }^{15}$ It was also used by Siebert in 1900 , and by Howitt and Siebert in 1904 for transcribing Diyari mythological texts. A slightly revised version was employed by Riedel in his unpublished 381-page translation of the Old Testament. ${ }^{16}$ The standard mission orthography is a fairly good representation of Diyari, although it generally over-differentiates the vowels and under-differentiates the consonants.

7 For a detailed history of the mission see Proeve and Proeve 1945, Hardy 1984, and Jones and Sutton 1986 (the last contains photographs of the mission and mission personalities in Chapters 2 and 3). The history is summarised in Austin (1981:12) and Ferguson 1987.

8 Lit. 'in the vagina', taking the name from a traditional Diyari story.

9 Lit. 'root in the hand'.

10 Anonymous 1870 . The primer was probably written by the missionary Koch.

11 Schoknecht 1871-73, translated into English by his son in 1947.

12 Both may be seen in the title of the primer, namely nujanujarajinkiniexa, which was later spelled ngujangujara jinkinietja (see the title of Reuther and Strehlow 1897).

13 Flierl 1880, 1884.

14 Reuther and Strehlow 1897.

15 The Reuther manuscript was translated into English by Scherer and published as Reuther 1981.

16 [1914?] The date of Riedel's manuscript has not been determined exactly. It is interesting that the manuscript has been heavily corrected and the spelling changed consistently throughout. The major corrections in evidence are discussed below. 
Diyari has three vowel phonemes: high front vowel $i$, high back vowel $u$, and low vowel $a$. In the mission orthography we find $a, i$, and $u$, as well as $e$ and $o$. The symbols $e$ and $o$ are used in several circumstances: in word-final position $e$ represents phonemic $i$ and $o$ represents phonemic $u$, as in the examples

tipe 'alive' for thipi

ngato ' $\mathrm{I}$ ' for ngathu

kulno 'one' for kurnu;

and in non-final position $e$ and $o$ represent phonemic $a$. The low vowel $a$ shows a wide range of phonetic (allophonic) variation in Diyari, ${ }^{17}$ including mid and low front and back vowels. The mid front vowel $[\varepsilon$ ] occurs following $y$ and preceding a laminal or apical stop or nasal, while low front [æ] occurs following $y$ and preceding an ' $\mathrm{r}$-sound' (see below). In the mission orthography both are spelled $e$, as in

jetai 'speaks' for yathayi

jeruja 'like that' for yaruya.

The mid back vowel [0] occurs between $w$ and a bilabial or dorso-velar stop or nasal, while low back [ $p$ ] occurs between $w$ and a retroflex sound. In the mission orthography these are spelled $o$, as in

wopai 'walks' for wapayi

worana 'who' for waranha.

For the consonants, we find the mission orthography under-differentiates stops, nasals and laterals, and rhotics ('r-sounds'). In the middle of words Diyari contrasts six points of articulation for stops and nasals, namely; bilabial, laminodental, apico-alveolar, laminopalatal, apico-domal and dorsovelar; that is $p, t h, t, j, r t$, and $k$. In the mission orthography $t h, t$, and $r t$ are not clearly distinguished. Similarly for nasals, lamino-dental $n h$ and apico-alveolar $n$ are not differentiated, nor is apico-domal $m$ consistently distinguished. Occasionally peculiar representations persist in all the mission materials, such as mishearing of kumu 'one' as kulno. Also in word-medial position Diyari has three 'r-sounds': a continuant $r$, a flap $r$, and a trill $r h{ }^{18}$ In the mission spelling system the trill is generally written $r$ and the other two are not differentiated. Thus, karrari 'today, now' is spelled karari

Interestingly, Riedel's translation of the Old Testament demonstrates a revised orthography which removes many of the $e$ and $o$ of the earlier writings (having ngatu for ' $\mathrm{I}$, for example). Also, the manuscript has been heavily corrected with many $r$ 's being changed to $r$, and $e$ and $o$ changed to $a$. We also find medial $n k$ corrected to $n g k$ (making a contrast missed in the earlier writings), and $n t j$ corrected to nitj. This revised orthography was not used by native speakers who wrote the language.

\section{Writings by Native Speakers.}

There is a body of material in Diyari written by native speakers of the language. This includes letters (reported by Berndt to be in the possession of T. Vogelsang, son of one of the Lutheran missionaries), ${ }^{19}$ and written texts.

17 See Austin 1981:20,21.

18 The trill does not contrast with $d$, and in Austin $1981 \mathrm{I}$ analysed it as an allophone of $d$. While this may be a possible analysis it does not represent the phonetic facts in a natural way.

19 Berndt 1957:174. He reported to me in 1978 that the letters were in his private collection. I have not seen this material. 
One text is based on a story told by Elias Palkalina; it was published by Berndt and Vogelsang in 193841. Although the authors state that 'In transcribing this Dieri text, the alphabet of the International Phonetic Association modified for Australian languages has been adhered to as closely as possible', ${ }^{20}$ the text is actually written in the mission orthography (see above), except that 1 has been substituted for $n g$. The text was transcribed by Vogelsang, who was himself fluent in Diyari and literate in the mission orthography.

The other texts by native speakers are those published by Fry in 1937. There are two sets of texts; the first were

dictated by an old Dieri native named Dintibana Kinjmilina, and known by the European name of Sam. He was brought up on the Mission station at Kopperamanna and taught to write ... The first series of legends were copied down by E. $[=\mathrm{T}$.] Vogelsang in my presence and later translated by him with the help of Sam. 21

As we might expect, these are written consistently in the mission orthography. The second set of texts were written by Dintibana himself. According to Fry,

a blank book was left with Sam ... Two months later the book arrived with the

following legends written by Sam in the Dieri language. Mr Vogelsang has trans-

lated these. . . As Sam wrote the Dieri himself, a word for word transcription has been made although the spelling is not consistent. ${ }^{22}$

The spellings are indeed inconsistent, with many apparent mistakes. It is not clear how many of these are genuine mis-spellings by Dintibana and how many are transcribers' and typesetters' errors. It would be interesting to analyse the original materials if the notebook mentioned by Fry could be found.

A final set of texts written by a native Diyari speaker and available for study are the postcards which are the subject of this paper. Here we are fortunate in having the originals available for scrutiny.

\section{The Maltilina Postcards.}

There are eight postcards written in the Diyari language by Rebecca Maltilina; three are dated 1909, three 1910, one 1913, and one is undated. The text on the cards varies in amount but all contain at least several sentences. There is no punctuation, except that the first word always begins with a capital and the last word before the signature is followed by a period. ${ }^{23}$ In Postcard 8 an underscore is used to hyphenate the word jinkangu, on the German model.

The Diyari on the cards is written fairly consistently in the mission orthography, although there are a few spelling errors (see below). A few English words appear on some of the cards,

20 Berndt and Vogelsang 1938-41:369.

21 Fry 1937:187.

22 Fry 1937:271.

23 Fry $(1937: 271)$ notes that in the texts written by Dintibana '[n]o punctuation marks were made by Sam, though he occasionally drew a line to mark the end of a sentence'. This suggests that Diyari writers probably did not consistently use punctuation. It is not clear whether this was because punctuation was not taught by the missionaries, or whether it is due to the writers' preferences. McGregor (pers. comm.) notes that literate and semi-literate speakers of Walmatjarri tend not to punctuate their writings. 
in all instances these English intrusions are for European concepts which have no Diyari equivalent: Postcard 1 ends with a Christmas and New Year wish in English, Postcard 3 contains week, Postcard 5 has please, and Postcard 7 has Christmas and nest week (for next week). A total of seventy-one Diyari roots are used in the texts, ${ }^{24}$ and there are fifteen grammatical suffixes to be found. Structurally, the language of the cards is identical to the language of the conversational texts recorded from present-day speakers.

The content of all the postcards is fairly similar: confirmation of receipt of letters, promises to write in future, statements that Rebecca is well, a little news (Postcard 2 tells of recent rain, and receipt of a photograph), and a final sentence jeruja ngato mudananto dakala, literally 'Like this I must finish writing', and the sign-off jinkani or jinkani kamanali, 'your' or 'your friend'.

The spelling in the postcards has some interesting features, including one or two revealing errors. The orthography follows the mission model closely, although there are a couple of inconsistencies; for example tipe, tepe and tepi for thipi 'alive, well', and warai and worai for warrayi 'aux-pres'. The status of $o$ and final $e$ in the mission spelling is discussed above.

There are several transpositions of letters, both in English (turly for truly in Postcard 1) and Diyari (kaklai for kalkai in Postcard 4). Two transpositions occur which are revealing of the relationship between the spelling system and Diyari phonology. Firstly, in Diyari (and several neighbouring languages) the nasals $n h$ and $n$, and the laterals $l h$ and $l$ can be optionally prestopped (to $d n h, d n, d l h$, and $d l$ respectively) after the first vowel of a word. ${ }^{25}$ Thus, 'nose, face' is mulha or mudlha. In Postcard 5 this word is spelled mulda with transposition of $l$ (actually $l h$ ) and the $d$ prestopping, suggesting that, at least as far as spelling is concerned, the prestopping is treated as a separate consonant sound. ${ }^{26}$ Secondly, the mission spelling inconsistently represents retroflex sounds, sometimes spelling them as $m, r l$, $r d$, and $r t$, and sometimes not differentiating them from the alveolar sounds $n, l$, and $t$. In Postcard 2 we find kudrai for kurdayi 'falls'. This transposition error shows that the two orthographic symbols are treated in the same way as two separate consonants would be.

There is a error in the spelling of nasal-stop consonant clusters, with the nasal being commonly omitted. Thus, nhingkirda appears as nikida in Postcard 2, nganjayi as ngatjai ${ }^{27}$ in Postcards 2 and 5, and mankirna as makinana in Postcard 5. This error is not consistent as we find mankina in Postcards 1 and 6, for example. However, there is a consistent misspelling of the cluster $n d r r$ following $u$. So, ngundrra 'think' is spelled ngudra in all instances where it occurs, and the ablative case pronoun nhung kangundrru appears as nunkangudru (Postcard 6); yet windrri is spelled windri in both its occurrences (Postcards 3 and 7).

It would be interesting to know if these mistakes are idiosyncratic or representative of literate Diyari. A comparison of these postcards and the other materials written by native speakers (see above) would be revealing.

24 See appended vocabulary.

25 Nasal prestopping is subject to the constraint that the word may not begin with a nasal (see Austin $1981: 18)$.

26 Notice also the error in Postcard 4 where yidni you' is spelled jindni.

27 There is a verb ngaja- in Diyari meaning 'to ask repetitively for, pray', but it seems that nganja- 'want' is intended here. 


\section{The Texts.}

This section consists of three components: a copy of the contents of the postcards exactly as written; a respelling of each Diyari word into the modern orthography with hyphens indicating separate morphemes, the text being divided into sentences, each beginning with a capital and ending in a period (this division is to some extent impressionistic, but Diyari has a relatively fixed word order making it easy in the majority of instances to determine where sentence breaks occur - in Diyari there is a strong tendency for verbs 'especially auxiliary verbs' to be sentence-final, and subject pronouns to be sentence-initial) ${ }^{28}$ and a morphemeby-morpheme gloss for each Diyari word ${ }^{29}$ At the end of each postcard text there is a running translation into English. I have attempted to make these translations as idiomatic as possible while retaining the flavour of the original. The texts are arranged in chronological order, as this can best be determined, except for Postcard 1 which is undated and carries no postmark.

Postcard 1. Undated. ${ }^{30}$

\begin{tabular}{|c|c|c|c|c|c|c|c|c|c|c|}
\hline $\begin{array}{l}\text { Kamanali } \\
\text { Kamanali } \\
\text { friend }\end{array}$ & $\begin{array}{l}\text { ngatjal } \\
\text { ngajalu } \\
\text { dear }\end{array}$ & & $\begin{array}{l}\text { pepa }^{32} \\
\text { pipa } \\
\text { рарег }\end{array}$ & $\begin{array}{l}\text { jinkani } \\
\text { yingkarni } \\
\text { your }\end{array}$ & $\begin{array}{l}\text { ngato } \\
\text { ngathu } \\
\text { I erg }\end{array}$ & $\begin{array}{l}\text { matja } \\
\text { maja } \\
\text { just }\end{array}$ & \multicolumn{4}{|c|}{$\begin{array}{l}\text { manina } \\
\text { mani-rna } \\
\text { get }\end{array}$} \\
\hline $\begin{array}{l}\text { warai } \\
\text { warra-yi } \\
\text { aux-pres }\end{array}$ & $\begin{array}{l}j a \\
y a \\
\text { and }\end{array}$ & $\begin{array}{l}\text { ngar } \\
\text { ngar } \\
\text { I }\end{array}$ & & $\begin{array}{l}\text { pirna } \\
\text { pirna } \\
\text { very }\end{array}$ & $\begin{array}{l}\operatorname{manki} \\
\text { manki- } \\
\text { be plea }\end{array}$ & $\begin{array}{l}n a \\
\text {-rna } \\
\text { ased-pto }\end{array}$ & & $\begin{array}{l}\text { par } \\
\text { par } \\
\text { aux }\end{array}$ & $\begin{array}{l}33 \\
a-y a . \\
\text { ast }\end{array}$ & $\begin{array}{l}\text { ngani } \\
\text { Nganhi } \\
\text { I }\end{array}$ \\
\hline $\begin{array}{l}\text { bakana } \\
\text { pakarna } \\
\text { also }\end{array}$ & $\begin{array}{l}\text { matja } \\
\text { maja } \\
\text { just }\end{array}$ & & $\begin{array}{l}\text { tipe } \\
\text { thipi } \\
\text { alive }\end{array}$ & $\begin{array}{l}\text { ngamai } \\
\text { ngama-yi. } \\
\text { sit-pres }\end{array}$ & $\begin{array}{l}n g \\
\mathrm{Ng} \\
\mathrm{I}\end{array}$ & $\begin{array}{l}\text { ato } \\
\text { gathu } \\
\text { erg }\end{array}$ & $\begin{array}{l}\text { wat } \\
? \\
?\end{array}$ & & $\begin{array}{l}\text { per } \\
\text { pip } \\
\text { par }\end{array}$ & \\
\hline
\end{tabular}

28 See Austin 1981:147-9.

29 Abbreviations used in the glosses are: ablat = ablative case; acc = accusative case; aux = auxiliary verb; dat $=$ dative case; emph = emphatic; erg = ergative case; $f u t=$ future tense $;$ imper $=$ imperative mood; impIDS = implicated, different subject; implSS = implicated, same subject; loc = locative case; nomin $=$ nominaliser; past $=$ past tense $; \mathrm{pl}=$ plural $;$ pres $=$ present tense $;$ tcple $=$ participle.

30 It is likely that the card was written is December since it concludes with a Christmas wish. There is no indication of the year.

31 This word does not appear in my Diyari materials. I interpret it as ngajalu 'dear'.

32 The word pepa is used throughout to indicate 'letter' or 'postcard' (the letters or cards from Dorothea do not seem to have survived). It is a borrowing from English 'paper', but notice that it is spelled as if it were a Diyari word, suggesting that it is a loan which has been fully incorporated into the language (compare the English intrusions noted, such as week and please).

33 This auxiliary verb indicates an action or event which occurred in the recent past, one or two weeks prior to the present (see Austin 1981:89,90).

34 The adjective thipi has the sense of 'alive, well-being' and can best be translated as 'well'. Note that Rebecca spells the word tipe, tepi, and tepe.

35 This word could not be identified; it may be a mis-spelling of walja (walya) 'soon, later'. 


\section{POSTCARDS AND DIYARI LITERACY}

\begin{tabular}{|c|c|c|c|c|c|c|}
\hline $\begin{array}{l}\text { jinpala } \\
\text { yinpa-lha } \\
\text { send-fut }\end{array}$ & $\begin{array}{l}\text { nganai } \\
\text { ngana-yi. } \\
\text { aux-pres }\end{array}$ & $\begin{array}{l}\text { karari } \\
\text { Karrari } \\
\text { today }\end{array}$ & $\begin{array}{l}\text { ngato } \\
\text { ngathu } \\
\text { I erg }\end{array}$ & \multicolumn{2}{|c|}{$\begin{array}{l}\text { ngankani } \\
\text { nganka-ni } \\
\text { work-nomin }\end{array}$} & $\begin{array}{l}\text { marapu } \\
\text { marrapu } \\
\text { much }\end{array}$ \\
\hline $\begin{array}{l}\text { ngamalkai } \\
\text { ngamalka-yi. } \\
\text { have-pres }\end{array}$ & $\begin{array}{l}\text { jeruja } \\
\text { Yaruya } \\
\text { like this }\end{array}$ & $\begin{array}{l}\text { ngato } \\
\text { ngathu } \\
\text { I erg }\end{array}$ & \multirow{2}{*}{\multicolumn{2}{|c|}{$\begin{array}{l}\text { mudananto } \\
\text { murda-rnanthu } \\
\text { finish-implDS }\end{array}$}} & \multirow{2}{*}{\multicolumn{2}{|c|}{$\begin{array}{l}\text { dakala } \\
\text { daka-lha } \\
\text { write-implSS }\end{array}$}} \\
\hline $\begin{array}{l}\text { jinkani } \\
\text { yingkarni } \\
\text { your }\end{array}$ & $R$. & & & & & \\
\hline
\end{tabular}

Wishing you a merry Christmas and a happy new year with best love from your turly. ${ }^{37}$ Rebecca Maltilena.

Dear friend, I got your letter and I was very glad. I am well too. I will send a letter later. Today I have much work. I must finish writing now. Your R. Wishing you a merry Christmas and a happy new year with best love from your turly. Rebecca Maltilena.

Postcard 2. May 161909.

$\begin{array}{llllll}\text { ngato } & \text { woltju } & \text { pepa } & \text { dakala } & \text { nganai } & \text { Dora } \\ \text { Ngathu } & \text { wulju } & \text { pipa } & \text { daka-lha } & \text { ngana-yi. } & \\ \text { I erg } & \text { long } & \text { paper } & \text { write-fut } & \text { aux-pres } & \end{array}$

$\begin{array}{lllllll}\text { kamanali } & \text { ngatjalu } & \text { ngato } & \text { pepa } & \text { jinkani } & \text { matja } & \text { manina } \\ \text { Kamanali } & \text { ngajalu } & \text { ngathu } & \text { pipa } & \text { yingkarni } & \text { maja } & \text { mani-rna } \\ \text { friend } & \text { dear } & \text { l erg } & \text { paper } & \text { your } & \text { just } & \text { get-ptcple }\end{array}$

$\begin{array}{lclllll}\text { warai } & \text { ja } & \text { ngani } & \text { matja } & \text { tipe } & \text { ngamai } & \text { wadaruja } \\ \text { warra-yi } & y a & \text { nganhi } & \text { maja } & \text { thipi } & \text { ngama-yi } & \text { wardaruya } \\ \text { aux-pres } & \text { and } & \text { I } & \text { just } & \text { alive } & \text { sit-pres } & \text { how } \\ \text { bakana } & \text { tipe } & \text { kariri } & \text { nikida } & \text { talara pirna } & \text { kudrai } \\ \text { pakarna } & \text { thipi. } & \text { Karrari } & \text { nhingkirda } & \text { thalara } & \text { pirna } & \text { kurda-yi } \\ \text { also } & \text { alive } & \text { today here } & \text { rain } & \text { big } & \text { fall-pres }\end{array}$

\begin{tabular}{|c|c|c|c|c|c|c|}
\hline$a$ & $\begin{array}{l}\text { kanta } \\
\text { kantha } \\
\text { grass }\end{array}$ & $\begin{array}{l}\text { pirna } \\
\text { pirna } \\
\text { big }\end{array}$ & $\begin{array}{l}\text { punkai } \\
\text { purnka-yi. } \\
\text { grow-pres }\end{array}$ & $\begin{array}{l}\text { ngato } \\
\text { Ngathu } \\
\text { I erg }\end{array}$ & $\begin{array}{l}\text { pirna } \\
\text { pirna } \\
\text { very }\end{array}$ & $\begin{array}{l}\text { ngatjai } \\
\text { nganja-yi } \\
\text { want }\end{array}$ \\
\hline
\end{tabular}

$\begin{array}{lllll}\text { bakana } & \text { jurana } & \text { najila } & \text { ngato } & \text { ngatata } \\ \text { pakarna } & \text { yurra-nha } & \text { nhayi-lha. } & \text { Ngathu } & \text { ngathata } \\ \text { also } & \text { you pl-acc } & \text { see-implSS } & \text { I erg } & \text { younger sibling }\end{array}$

36 The use of the implicated-different subject suffix -rnanthu in a main clause to indicate necessity is a common occurrence in Diyari (see Austin 1981:203-4).

37 Mis-spelling of truly.

38 It is likely that this sentence was intended as a postscript.

39 Note the transposition of the $d$ and $r$ in this spelling. 
ABORIGINAL HISTORY 1986 10:2

\begin{tabular}{|c|c|c|c|c|c|c|c|}
\hline \multicolumn{2}{|c|}{$\begin{array}{l}\text { wakaja } \\
\text { waka-ya } \\
\text { small-dat }\end{array}$} & $\begin{array}{l}\text { pepa } \\
\text { pipa } \\
\text { pарет }\end{array}$ & $\begin{array}{l}\text { mudla } 40 \\
\text { mudlha } \\
\text { face }\end{array}$ & $\begin{array}{l}\text { matja } \\
\text { maja } \\
\text { just }\end{array}$ & $\begin{array}{l}\text { manina } \\
\text { mani-rna } \\
\text { get-ptcple }\end{array}$ & \multicolumn{2}{|c|}{$\begin{array}{l}\text { warai } \\
\text { warra-yi } \\
\text { aux-pres }\end{array}$} \\
\hline $\begin{array}{l}j a \\
y a \\
\text { and }\end{array}$ & $\begin{array}{l}\text { ngani } \\
\text { nganhi } \\
\text { I }\end{array}$ & $\begin{array}{l}\text { pir } \\
\text { pir } \\
\text { ver }\end{array}$ & $\begin{array}{l}\text { manki } \\
\text { manki } \\
\text { be ple }\end{array}$ & $\begin{array}{l}\text { na } \\
\text { asna } \\
\text { ased-ptcple }\end{array}$ & $\begin{array}{l}\text { warai } \\
\text { warra-yi } \\
\text { aux-pres }\end{array}$ & $\begin{array}{l}\text { nina } \\
\text { nhinha } \\
\text { him }\end{array}$ & $\begin{array}{l}\text { najila } \\
\text { nhayi-lha } \\
\text { see-implSS }\end{array}$ \\
\hline $\begin{array}{l}y a \\
\text { and }\end{array}$ & \multicolumn{2}{|c|}{$\begin{array}{l}\text { kamanali } \\
\text { kamanali } \\
\text { friend }\end{array}$} & $\begin{array}{l}\text { ngatjalu } \\
\text { ngajalu } \\
\text { dear }\end{array}$ & $\begin{array}{l}\text { ngato } \\
\text { ngathu } \\
\text { I erg }\end{array}$ & $\begin{array}{l}\text { bakana } \\
\text { pakarna } \\
\text { also }\end{array}$ & $\begin{array}{l}\text { jidna } \\
\text { yidnha } \\
\text { you acc }\end{array}$ & $\begin{array}{l}\text { pirna } \\
\text { pirna } \\
\text { very }\end{array}$ \\
\hline \multicolumn{2}{|c|}{$\begin{array}{l}\text { ngudrai } \\
\text { ngundrra-yi } \\
\text { think-pres }\end{array}$} & $\begin{array}{l}j a \\
y a \\
\text { and }\end{array}$ & $\begin{array}{l}\text { ngatjai } \\
\text { nganja-yi } \\
\text { want-pres }\end{array}$ & $\begin{array}{l}\text { jalalu } \\
\text { yarlarlu } \\
\text { together }\end{array}$ & $\begin{array}{l}\text { ngamala } \\
\text { ngama-lha. } \\
\text { live-implSs }\end{array}$ & \multicolumn{2}{|c|}{$\begin{array}{l}\text { ngato } \\
\text { Ngathu } \\
\text { I eIg }\end{array}$} \\
\hline \multicolumn{2}{|c|}{$\begin{array}{l}\text { jidna }^{41} \\
\text { yidnha } \\
\text { you acc }\end{array}$} & $\begin{array}{l}\text { matja } \\
\text { maja } \\
\text { just }\end{array}$ & $\begin{array}{l}\text { thipi } \\
\text { alive }\end{array}$ & $\begin{array}{l}\text { ngamai } \\
\text { ngama-yi. } \\
\text { sit-pres }\end{array}$ & $\begin{array}{l}\text { jeruja } \\
\text { Yaruya } \\
\text { like this }\end{array}$ & $\begin{array}{l}\text { ngathu } \\
\text { I erg }\end{array}$ & \\
\hline \multicolumn{3}{|c|}{$\begin{array}{l}\text { mudananto } \\
\text { murda-rnanthu } \\
\text { stop-implDS }\end{array}$} & $\begin{array}{l}\text { akala } \\
\text { aka-lha. } \\
\text { rite-implSS }\end{array}$ & $\begin{array}{l}\text { jinkani } \\
\text { Yingkarni } \\
\text { your }\end{array}$ & \multicolumn{2}{|c|}{ R. Maltilina } & \\
\hline
\end{tabular}

I will write you a long letter. Dora dear friend I just got your letter and I am well like [you] are well too. Today it rained a lot here and lots of grass has come up. I really want to see you all. I have got my younger brother's photograph and I was very glad to see him and dear friend I also think of you very much and want to live together [with you] . I you ... just am well. I must finish writing now. Your R. Maltilina.

Postcard 3. Postmarked August 181909.

$\begin{array}{lllllll}\text { Dori } & \text { kamanali } & \text { ngatjalu } & \text { ngato } & \text { ngudrai } & \text { jidni } & \text { pepani } \\ & \text { Kamanali } & \text { ngajalu } & \text { ngathu } & \text { ngundrra-yi } & \text { yini } & \text { pipa-nhi } \\ & \text { friend } & \text { dear } & \text { I erg } & \text { think } & \text { you } & \text { paper-loc }\end{array}$

\begin{tabular}{|c|c|c|c|c|}
\hline $\begin{array}{l}\text { kalkai } \\
\text { karlka-yi. } \\
\text { wait-pres }\end{array}$ & $\begin{array}{l}\text { wata ngudru } \\
\text { Wata ngundrra- } \emptyset \\
\text { not think-imper }\end{array}$ & $\begin{array}{l}\text { ngato } \\
\text { ngathu } \\
\text { I erg }\end{array}$ & $\begin{array}{l}\text { jidna } \\
\text { yidnha } \\
\text { you acc }\end{array}$ & $\begin{array}{l}\text { kuriter }^{43} \\
\text { kurrutharrha(-rna) } \\
\text { forget(-ptcple) }\end{array}$ \\
\hline
\end{tabular}

40 The expression pepa mudla is literally 'paper face'; I have translated it as 'photograph'.

41 This seems to be a false start with the sentence beginning 'I you' and ending with an intransitive predicate.

42 This seems to be a mis-spelling of the imperative verb form ngundrra.

43 The participial suffix $n a$ ( $-m a$ in Austin's spelling) is obligatory before the auxiliary verb warra-yi (see Austin 1981:87, 89); it is missing here. 
POSTCARDS AŃD DIYARI LITERACY

\begin{tabular}{|c|c|c|c|c|c|c|c|c|}
\hline $\begin{array}{l}\text { warai } \\
\text { warra-yi. } \\
\text { aux-pres }\end{array}$ & $\begin{array}{l}\text { ngato } \\
\text { Ngathu } \\
\text { I erg }\end{array}$ & \multicolumn{2}{|c|}{$\begin{array}{l}\text { ngurali } \\
\text { ngurrha-li } \\
\text { always-erg }\end{array}$} & \multicolumn{2}{|c|}{$\begin{array}{l}\text { ngudrana } \\
\text { ngundrra-rna } \\
\text { think-ptcple }\end{array}$} & \multicolumn{2}{|r|}{$\begin{array}{l}\text { warai } \\
\text { warra-yi } \\
\text { aux-pres }\end{array}$} & $\begin{array}{l}\text { dakala } \\
\text { daka-lh } \\
\text { write-ir }\end{array}$ \\
\hline $\begin{array}{l}\text { ngani } \\
\text { Nganhi } \\
\text { I }\end{array}$ & $\begin{array}{l}\text { matja } \\
\text { maja } \\
\text { just }\end{array}$ & $\begin{array}{l}\text { tipe } \\
\text { thipi } \\
\text { alive }\end{array}$ & $\begin{array}{l}\text { ngamai } \\
\text { ngama-yi } \\
\text { sit-pres }\end{array}$ & & $\begin{array}{l}j a \\
y a \\
\text { and }\end{array}$ & $\begin{array}{l}\text { wado } \\
\text { ward } \\
\text { how }\end{array}$ & $\begin{array}{l}\text { laru } \\
\text { daru }\end{array}$ & $\begin{array}{l}a \\
r r a \\
\mathrm{pl} l\end{array}$ \\
\hline $\begin{array}{l}\text { bakana } \\
\text { pakarna } \\
\text { also }\end{array}$ & $\begin{array}{l}\text { tipe } \\
\text { thipi } \\
\text { alive }\end{array}$ & $\begin{array}{l}\text { nganai } \\
\text { ngana-yi } \\
\text { be-pres }\end{array}$ & $\begin{array}{c}\text { ngato } \\
\text { Ngath } \\
\text { I erg }\end{array}$ & $\begin{array}{l}\text { to } \\
\text { thu } \\
\text { g }\end{array}$ & $\begin{array}{l}\text { windri } \\
\text { windrri } \\
\text { only }\end{array}$ & & $\begin{array}{l}\text { jaura } \\
\text { yawarrha } \\
\text { word }\end{array}$ & $\begin{array}{l}\text { palpa } \\
\text { parlpa } \\
\text { few }\end{array}$ \\
\hline $\begin{array}{l}\text { dakai } \\
\text { daka-yi } \\
\text { write-pres }\end{array}$ & $\begin{array}{l}\text { ngato } \\
\text { Ngathu } \\
\text { I erg }\end{array}$ & wet & $\begin{array}{l}\text { kulno } \\
\text { kumu } \\
\text { one }\end{array}$ & $\begin{array}{l}\text { pepa } \\
\text { pipa } \\
\text { paper }\end{array}$ & $\begin{array}{l}d a k \\
d a k \\
\text { wri }\end{array}$ & $\begin{array}{l}\text { ala } \\
\text { a-lha. } \\
\text { te-fut }\end{array}$ & $\begin{array}{l}\text { ngar } \\
N g a \\
\text { aux }\end{array}$ & $\begin{array}{l}\text {-yi. } \\
\text { res }\end{array}$ \\
\hline $\begin{array}{l}\text { jeruja } \\
\text { Yaruya } \\
\text { like this }\end{array}$ & $\begin{array}{l}\text { ngato } \\
\text { ngathu } \\
\text { I erg }\end{array}$ & $\begin{array}{l}\text { mud } \\
\text { murc } \\
\text { finisl }\end{array}$ & $\begin{array}{l}\text { nanto } \\
\text { z-rnanthu } \\
\text {-implDS }\end{array}$ & & $\begin{array}{l}\text { kala } \\
\text { ka-lha } \\
\text { rite-impls }\end{array}$ & & $\begin{array}{l}\text { ngani } \\
\text { nganhi } \\
\text { I }\end{array}$ & \\
\hline $\begin{array}{l}\text { jinkani } \\
\text { yingkarni } \\
\text { your }\end{array}$ & $\begin{array}{l}\text { kaman } \\
\text { kaman } \\
\text { friend }\end{array}$ & $\begin{array}{l}\text { nali } \\
\text { nali }\end{array}$ & $\begin{array}{l}\text { atjalu. } \\
\text { ajalu. } \\
\text { ar }\end{array}$ & Rebec & cca $M$ & & & \\
\hline
\end{tabular}

Dori dear friend, I think you are waiting for a letter. Do not think I have forgotten you. I always think about writing. I am well and are you all well too? I am only writing a few words. In one week I will write a letter. I must finish writing now. I am your dear friend. Rebecca M.

Postcard 4. Postmarked November 241909.

\begin{tabular}{|c|c|c|c|c|c|}
\hline dear Dorie & $\begin{array}{l}\text { ngato } \\
\text { Ngathu } \\
\text { I erg }\end{array}$ & $\begin{array}{l}\text { ngt } \\
\text { ngu } \\
\text { thi }\end{array}$ & $\begin{array}{l}\text { rai } \\
d r r a-y i \\
\text { c-pres }\end{array}$ & $\begin{array}{l}\text { jindni } \\
\text { yidni } \\
\text { you }\end{array}$ & melinguru $^{45}$ \\
\hline $\begin{array}{l}\text { pepani } \\
\text { pipa-nhi } \\
\text { paper-loc }\end{array}$ & $\begin{array}{l}\text { kaklai }^{46} \\
\text { karlka-yi. } \\
\text { wait-pres }\end{array}$ & $\begin{array}{l}\text { ngani } \\
\text { Nganhi } \\
\text { I }\end{array}$ & $\begin{array}{l}\text { pirna } \\
\text { pirna } \\
\text { very }\end{array}$ & $\begin{array}{l}\text { walkarali }{ }^{47} \\
\text { walkarrha-li } \\
\text { sad-erg }\end{array}$ & $\begin{array}{l}\text { ngana } 48 \\
\text { ngana-yi } \\
\text { be-pres }\end{array}$ \\
\hline
\end{tabular}

44 Note the mis-spelling of jidni.

45 The word milinguru, occurs in mission materials with the gloss 'always'; it was not used by my consultants.

46 Notice the transposition of letters here; kalkai would be correct.

47 The ergative case is used with certain abstract nouns when they function predicatively with the copula verb ngana- 'to be' (see Austin 1981:105, 121).

48 The present tense suffix $i$ ( $y i$ in Austin's spelling) is missing here. 
ABORIGINAL HISTORY $1986 \quad$ 10:2

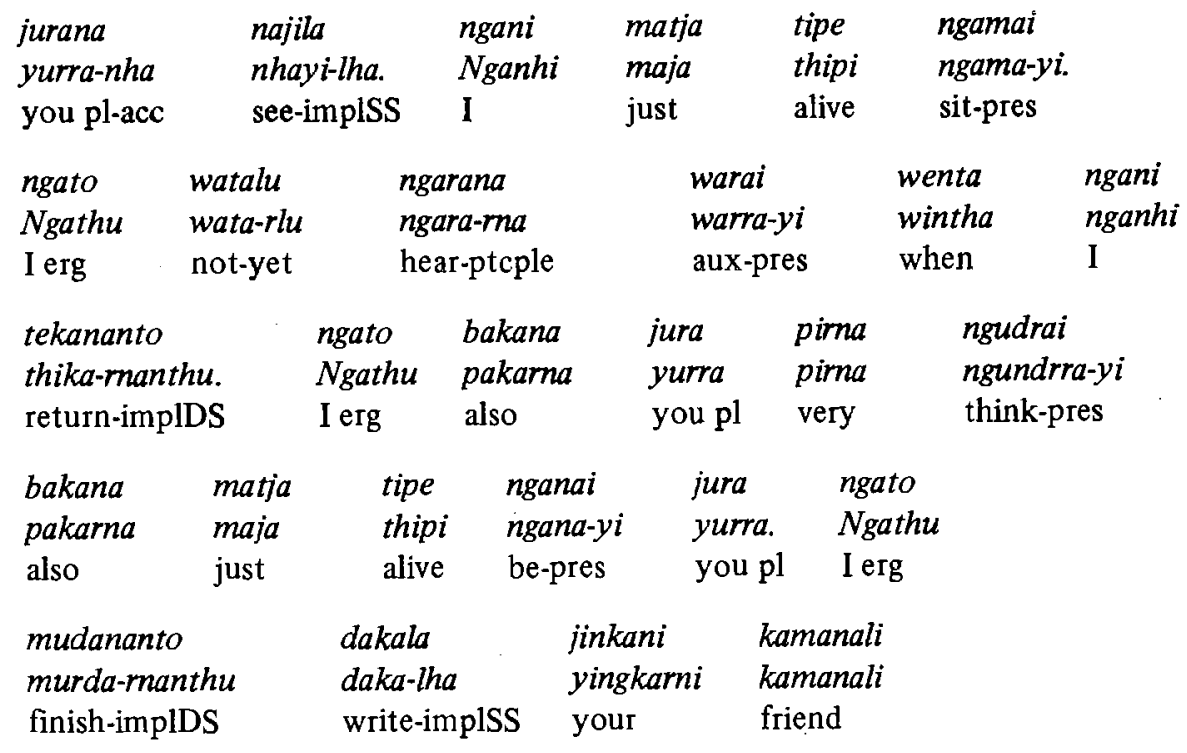

[Upside-down above POST ]

$\begin{array}{lll}\text { kalala } & \text { dakamai } & \text { nurejali }^{49} \\ \text { kalarla } & \text { daka- } \emptyset \text {-mayi } & \text { nhurrhu-yali } \\ \text { in return } & \text { write-imper-emph } & \text { quickly-erg }\end{array}$

Dear Dorie. I think you have been waiting for a letter for a long time. I am longing to see you all. I am well. I have not heard yet when I must return. I too think about you all a lot. You are all well too. I must finish writing. Your friend.

[Upside-down above POST] Write back quickly!

Postcard 5. Postmarked July 61910.

\begin{tabular}{|c|c|c|c|c|c|c|}
\hline $\begin{array}{l}\text { Kamanali } \\
\text { Kamanali } \\
\text { friend }\end{array}$ & \multicolumn{2}{|c|}{$\begin{array}{l}\text { ngatialu } \\
\text { ngajalu } \\
\text { dear }\end{array}$} & $\begin{array}{l}\text { pepa } \\
\text { pipa } \\
\text { paper }\end{array}$ & $\begin{array}{l}\text { jinkani } \\
\text { yingkarni } \\
\text { your }\end{array}$ & $\begin{array}{l}\text { matja } \\
\text { maja } \\
\text { just }\end{array}$ & $\begin{array}{l}\text { manina } \\
\text { mani-rna } \\
\text { get }\end{array}$ \\
\hline $\begin{array}{l}\text { warai } \\
\text { warra-yi } \\
\text { aux-pres }\end{array}$ & $\begin{array}{l}j a \\
y a \\
\text { and }\end{array}$ & $\begin{array}{l}\text { ngani } \\
\text { nganhi } \\
\text { I }\end{array}$ & $\begin{array}{l}\text { pirna } \\
\text { pirna } \\
\text { very }\end{array}$ & $\begin{array}{l}\operatorname{manki} \\
\text { manki } \\
\text { be ple }\end{array}$ & -ptcple & $\begin{array}{l}\text { paraja } \\
\text { parrha-ya } \\
\text { aux-past }\end{array}$ \\
\hline $\begin{array}{l}\text { ngato } \\
\text { Ngathu } \\
\text { I erg }\end{array}$ & $\begin{array}{l}\text { pirna } \\
\text { pirna } \\
\text { very }\end{array}$ & $\begin{array}{l}\text { ngatj } \\
\text { nganj } \\
\text { like- }\end{array}$ & $\begin{array}{l}a i \\
j a-y i \\
\text { pres }\end{array}$ & $\begin{array}{l}\text { nunkani }^{50} \\
\text { nhungkarn } \\
\text { his }\end{array}$ & $\begin{array}{l}\text { pepa } \\
\text { pipa } \\
\text { paper }\end{array}$ & $\begin{array}{l}\text { mudla } \\
\text { mudlha } \\
\text { face }\end{array}$ \\
\hline
\end{tabular}

49 This is a mis-spelling of nurujeli (nhurrhu-yali in Austin's orthography); compare the spelling in Postcard 5.

50 The identity of 'he' is unknown. 


\section{POSTCARDS AND DIYARI LITERACY}

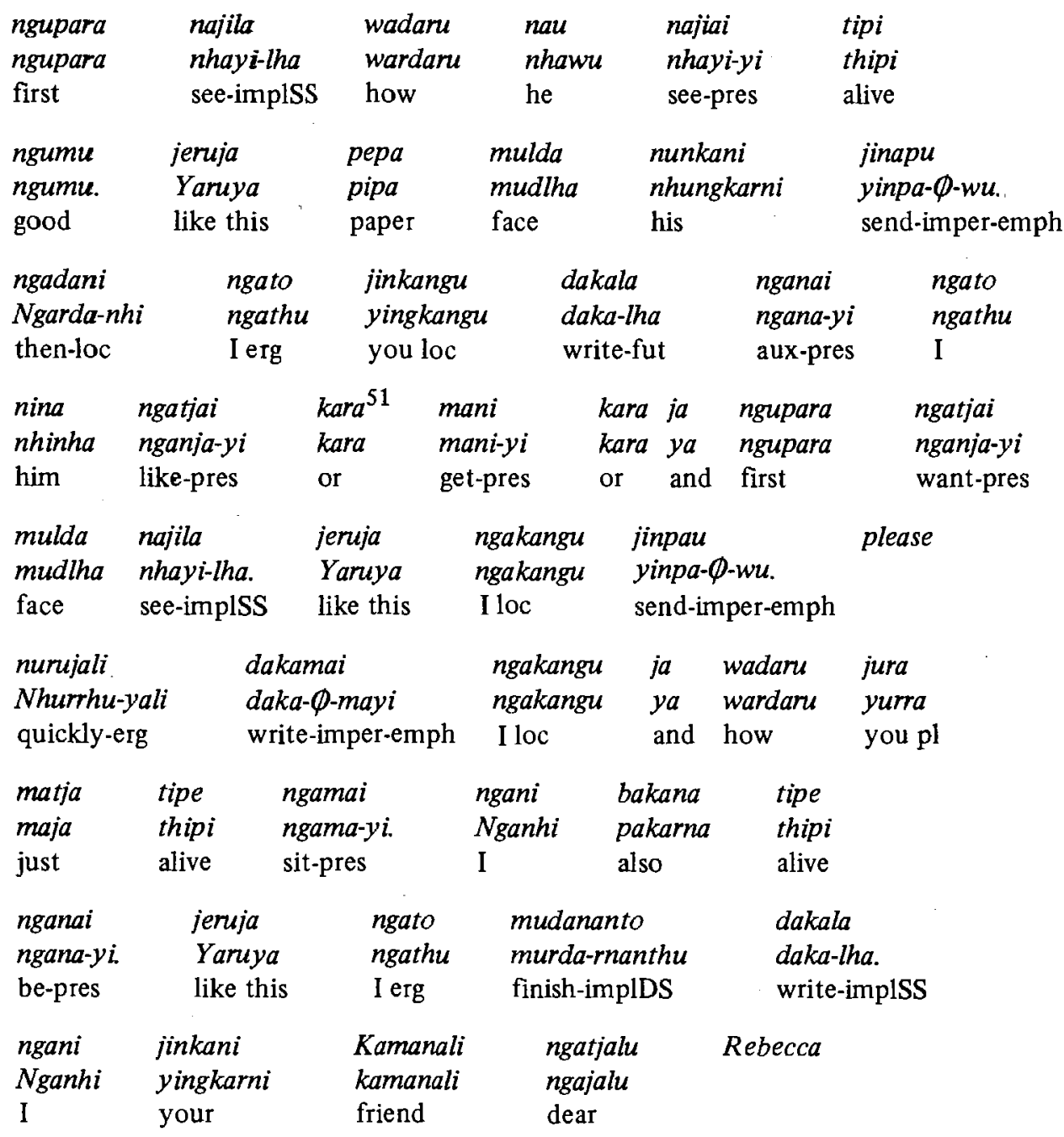

Dear friend, I just received your letter and I was very glad. I really liked to see his photograph for the first time and [to see] that he looks very well. Like this send me his photograph. And then I will write to you if I want it or get it, and want to see the face [photograph] first. Send it to me like this please. Write to me quickly and how you are all well. I am well too. I must finish writing now. Your dear friend Rebecca.

Postcard 6. Dated: th 251910 [postmark possibly 30 JE, i.e. 30 June] .

$\begin{array}{lllllll}\text { Kamanali } & \text { ngatalu } & \text { ngato } & \text { pepa } & \text { jinkani } & \text { matja } & \text { manina } \\ \text { Kamanali } & \text { ngajalu } & \text { ngathu } & \text { pipa } & \text { yingkarni } & \text { maja } & \text { mani-rna } \\ \text { friend } & \text { dear } & \text { I } \notin \text { rg } & \text { paper } & \text { your } & \text { just } & \text { get-ptcple }\end{array}$

51 The disjunction particle kara is used twice to emphasise the exclusive disjunction of the two sentences (see Austin 1981:235). 


\begin{tabular}{|c|c|c|c|c|c|c|}
\hline $\begin{array}{l}\text { warai } \\
\text { warra-yi } \\
\text { aux-pres }\end{array}$ & $\begin{array}{l}j a \\
y a \\
\text { and }\end{array}$ & $\begin{array}{l}\text { ngani } \\
\text { nganhi } \\
\text { I }\end{array}$ & $\begin{array}{l}\text { pirna } \\
\text { pirna } \\
\text { very }\end{array}$ & $\begin{array}{l}\text { mankina } \\
\text { manki-rna } \\
\text { be pleased-ptcple }\end{array}$ & $\begin{array}{l}\text { warai } \\
\text { warra-y } \\
\text { aux-pre }\end{array}$ & \\
\hline $\begin{array}{l}\text { ngani } \\
\text { Nganhi } \\
\text { I }\end{array}$ & $\begin{array}{l}\text { matja } \\
\text { maja } \\
\text { just }\end{array}$ & $\begin{array}{l}\text { tipe } \\
\text { thipi } \\
\text { alive }\end{array}$ & $\begin{array}{l}\text { nganai } \\
\text { ngana-yi. } \\
\text { be-pres }\end{array}$ & $\begin{array}{l}\text { ngato } \\
\text { Ngathu } \\
\text { I erg }\end{array}$ & $\begin{array}{l}\text { bakana } \\
\text { pakarna } \\
\text { also }\end{array}$ & $\begin{array}{l}\text { matja } \\
\text { maja } \\
\text { just }\end{array}$ \\
\hline $\begin{array}{l}\text { pepa } \\
\text { pipa } \\
\text { paper }\end{array}$ & \multicolumn{2}{|c|}{$\begin{array}{l}\text { nunkangudru } \\
\text { nhungkangundrru } \\
\text { him ablat }\end{array}$} & $\begin{array}{l}\text { manina } \\
\text { mani-rna } \\
\text { get-ptcple }\end{array}$ & $\begin{array}{l}\text { warai } \\
\text { warra-yi. } \\
\text { aux-pres }\end{array}$ & $\begin{array}{l}\text { nulu } \\
\text { Nhulu } \\
\text { he erg }\end{array}$ & \\
\hline $\begin{array}{l}\text { ngakangu } \\
\text { ngakangu } \\
\text { me dat }\end{array}$ & \multicolumn{2}{|c|}{$\begin{array}{l}\text { dakana } \\
\text { daka-rna } \\
\text { write-ptcple }\end{array}$} & $\begin{array}{l}\text { warai } \\
\text { warra-yi. } \\
\text { aux-pres }\end{array}$ & $\begin{array}{l}\text { jeruja } \\
\text { Yaruya } \\
\text { like this }\end{array}$ & $\begin{array}{l}\text { Kamanali } \\
\text { kamanali } \\
\text { friend }\end{array}$ & $\begin{array}{l}\text { ngatjalu } \\
\text { ngajalu } \\
\text { dear }\end{array}$ \\
\hline $\begin{array}{l}\text { ngato } \\
\text { ngathu } \\
\text { I erg }\end{array}$ & $\begin{array}{l}\text { bakana } \\
\text { pakarna } \\
\text { also }\end{array}$ & $\begin{array}{l}\text { pepa } \\
\text { pipa } \\
\text { paper }\end{array}$ & $\begin{array}{l}\text { jinkangu } \\
\text { yingkangu } \\
\text { you dat }\end{array}$ & $\begin{array}{l}\text { dakai } \\
\text { daka-yi. } \\
\text { write-pre }\end{array}$ & $\begin{array}{l}\text { jeruja } \\
\text { Yaruya } \\
\text { like this }\end{array}$ & \\
\hline $\begin{array}{l}\text { ngato } \\
\text { ngathu } \\
\text { I erg }\end{array}$ & $\begin{array}{l}\text { mudanai } \\
\text { murda-ri } \\
\text { finish-im }\end{array}$ & $\begin{array}{l}\text { nthu. } \\
\text { IDS }\end{array}$ & $\begin{array}{l}\text { jinkani } \\
\text { Yingkarni } \\
\text { your }\end{array}$ & R. Maltilina & & \\
\hline
\end{tabular}

[Upside-down]

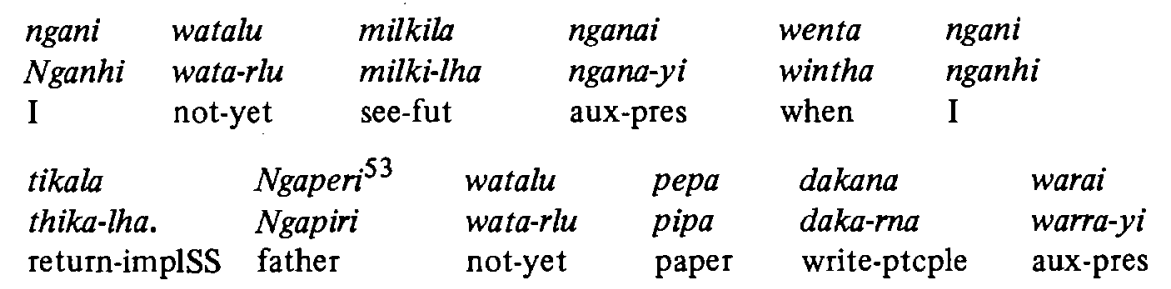

Dear friend I just got your letter and I was very pleased. I am well. I also received a letter from him. He wrote to me. So dear friend I am writing a letter to you. I must finish now. Your R. Maltilina.

[Upside-down] I have not seen yet when I will return. Father has not written a letter yet.

52 The identity of 'he' is unknown.

53 Note the use of the capital in Ngaperi 'Father'. It is likely that the reference is to Hermann Vogelsang who was known at Killalpaninna mission as 'Father' (see Proeve and Proeve 1946). 
Postcard 7. Dated: December th 181910.

$\begin{array}{llllll}\text { Dear dorie } & \text { ngato } & \text { windri } & \text { jaura } & \text { palpa } & \text { dakai } \\ & \text { ngathu } & \text { windrri } & \text { yawarrha } & \text { parlpa } & \text { daka-yi. } \\ & \text { I erg } & \text { only } & \text { word } & \text { some } & \text { write-pres }\end{array}$

$\begin{array}{llclll}\text { ngato } & \text { ngudrai } & \text { jura } & \text { matja } & \text { tipe } & \text { ngamai } \\ \text { Ngathu } & \text { ngundrra-yi } & \text { yurra } & \text { maja } & \text { thipi } & \text { ngama-yi } \\ \text { I erg } & \text { think-pres } & \text { you pl just } & \text { alive } & \text { sit-pres } \\ \text { ngani } & \text { bakana } & \text { tipe } & \text { nganai } & \text { ngato } & \text { wata } \\ \text { Nganhi } & \text { pakarna } & \text { thipi } & \text { ngana-yi. } & \text { Ngathu } & \text { wata } \\ \text { I } & \text { also } & \text { alive } & \text { be-pres } & \text { I erg } & \text { not }\end{array}$

$\begin{array}{llllll}\text { jaura } & \text { marapu } & \text { dakai } & \text { ngato } & \text { ngudrai } & \text { jura } \\ \text { yawarha } & \text { marrapu } & \text { daka-yi. } & \text { Ngathu } & \text { ngundrra-yi } & \text { yurra } \\ \text { word } & \text { many } & \text { write } & \text { I erg } & \text { think-pres } & \text { you pl }\end{array}$

$\begin{array}{llllll}\text { bakana } & \text { ditji } & \text { ngumu } & \text { Christmas } & \text { ngamalkala } & \text { nganai } \\ \text { pakarna } & \text { diji } & \text { ngumu } & & \text { ngamalka-lha } & \text { ngana-yi. } \\ \text { also } & \text { day } & \text { good } & & \text { have-fut } & \text { aux-pres }\end{array}$

\begin{tabular}{|c|c|c|c|c|c|c|}
\hline $\begin{array}{l}\text { ngato } \\
\text { Ngathu } \\
\text { I erg }\end{array}$ & $n e s t^{54}$ & week & $\begin{array}{l}\text { ngakani } \\
\text { ngakarni } \\
\text { my }\end{array}$ & $\begin{array}{l}\text { marapu } \\
\text { marrapu } \\
\text { many }\end{array}$ & $\begin{array}{l}\text { ngamakala } \\
\text { ngamalka-lha } \\
\text { have-fut }\end{array}$ & $\begin{array}{l}\text { ngamakai } \\
\text { ngana-yi. } \\
\text { aux-pres }\end{array}$ \\
\hline
\end{tabular}

$\begin{array}{llllll}\text { jeruja } & \text { ngato } & \text { mudananto } & \text { dakala } & \text { ngani } & \text { jinkani } \\ \text { Yanuya } & \text { ngathu } & \text { murda-rnanthu } & \text { daka-lha. } & \text { Nganhi } & \text { yingkarni } \\ \text { like this } & \text { I erg } & \text { finish-implDS } & \text { write-implSS } & \text { I } & \text { your }\end{array}$

Kamanali ngatjalu Rebecca. best love to all.

kamanali ngajalu

friend dear

Dear Dorie, I am only writing a few words. I think you are all well. I am well too. I am not writing many words. I think you all will have a good day at Christmas too. Next week I have my many. I must finish writing. I am your dear friend Rebecca. best love to all.

Postcard 8. Dated: th 91913 [no month given].

$\begin{array}{lllllll}\text { Kamanali } & \text { ngatjilu } & \text { ngato } & \text { pepa } & \text { matja } & \text { manina } & \text { worai } \\ \text { Kamanali } & \text { ngajalu } & \text { ngathu } & \text { pipa } & \text { maja } & \text { mani-rna } & \text { warra-yi. } \\ \text { friend } & \text { dear } & \text { I erg } & \text { paper } & \text { just } & \text { get-ptcple } & \text { aux-pres }\end{array}$

54 The spelling nest for next is interesting in that it probably represents Rebecca's usual pronunciation (consonant cluster simplification being a feature of Aboriginal English).

55 The spelling ngamakala for ngamalkala is an error, as is the following word which must have been intended as the future tense auxiliary nganai.

56 The auxiliary is elsewhere spelled warai. 
ABORIGINAL HISTORY $1986 \quad 10: 2$

$\begin{array}{lllllll}\text { ngani } & \text { matja } & \text { tipe } & \text { ngamai } & \text { ja } & \text { wodaru } & \text { jura } \\ \text { Nganhi } & \begin{array}{l}\text { maja } \\ \text { I }\end{array} & \text { thipi } & \text { ngama-yi } & \text { ya } & \text { wardaru } & \text { yurra } \\ \text { I } & \text { alive } & \text { sit-pres } & \text { and } & \text { how } & \text { you } \mathrm{pl} \\ \text { bakana } & \text { tipe } & \text { ngato } & \text { karari } & \text { bakana } & \text { Sophienangu } \\ \text { pakarna } & \text { thipi. } & \text { Ngathu } & \text { karrari } & \text { pakarna } & \text { Sophie-nhangu } \\ \text { also } & \text { alive } & \text { I erg } & \text { today } & \text { also } & \text { Sophie-loc } \\ \text { pepa } & \text { dakai } & \text { jeruja } & \text { ngato } & \text { bakana } & \text { wolja } \\ \text { pipa } & \text { daka-yi. } & \text { Yaruya } & \text { ngathu } & \text { pakarna } & \text { walya } \\ \text { paper } & \text { write-pres } & \text { like this } & \text { I erg } & \text { also } & \text { soon } \\ \text { jinka-ngu } & \text { pepa } & \text { dakala } & \text { nganai } & \text { ngani } & \text { jinkani } \\ \text { yingkangu } & \text { pipa } & \text { daka-lha } & \text { ngana-yi. } & \text { Nganhi } & \text { yingkarni } \\ \text { you dat } & \text { paper } & \text { write-fut } & \text { aux-pres } & \text { I } & \text { your }\end{array}$

Rebecca.

Dear friend I just got the letter. I am well and just as you are well too. Today I am writing a letter to Sophie too. Like this, I will write a letter to you later. I am your Rebecca.

Vocabulary.

The following is a list of all the vocabulary items used in the postcards, their spelling in the current orthography, and the relevant gloss.

\begin{tabular}{|c|c|c|}
\hline Maltilina spelling & Austin spelling & Gloss \\
\hline bakana & pakarna & also \\
\hline dakai & $d a k a \cdot y i$ & write-pres \\
\hline dakala & daka-lha & write-implSS \\
\hline dakamai & $d a k a-\emptyset-m a i$ & write-imper-emph \\
\hline ditji & $d i j i$ & day \\
\hline$j a$ & $y a$ & and \\
\hline jalalu & yarlarlu & together \\
\hline jaura & yawarrha & word \\
\hline jeruja & yaruya & like this \\
\hline jidna & yidnha & you acc \\
\hline$j i d n i$ & $y i d n i$ & you \\
\hline jinkangu & yingkangu & you loc \\
\hline jinkani & yingkarni & your \\
\hline jinpala & yinpa-lha & send-fut \\
\hline jinpau & yinpa- $\theta-w u$ & send-imper-emph \\
\hline jura & yurra & you $\mathrm{pl}$ \\
\hline jurana & yurra-nha & you pl-acc \\
\hline kaklai & $k a r l k a \cdot y i$ & wait-pres \\
\hline kalala & kalarla & in return \\
\hline kalkai & $k a r l k a-y i$ & wait-pres \\
\hline kamanali & kamanali & friend \\
\hline kanta & kantha & grass \\
\hline
\end{tabular}


POSTCARDS AND DIYARI LITERACY

\begin{tabular}{|c|c|c|}
\hline kara & kara & or, either ... or \\
\hline karari & karrari & today, now \\
\hline kudrai & $k u r d a-y i$ & fall-pres \\
\hline kulno & kurnu & one \\
\hline kuriteri & kurrutharrha-yi & forget-pres \\
\hline manina & mani-rna & get-ptcple \\
\hline mankina & manki-rna & be pleased-ptcple \\
\hline marapu & marrapu & many \\
\hline matja & maja & just \\
\hline melinguru & $?$ & $?$ \\
\hline milkila & milk-lha & see-fut \\
\hline mudananto & murda-rnanthu & finish-implDS \\
\hline mudla & mudlha & face \\
\hline mulda & mudlha & face \\
\hline najila & nhayi-lha & see-implSS \\
\hline ngadani & ngarda-nhi & then-loc \\
\hline ngakangu & ngakangu & I loc \\
\hline ngamai & ngama-yi & sit-pres \\
\hline ngamakala & ngamalka-lha & have-fut \\
\hline ngamalkai & ngamalka-yi & have-pres \\
\hline nganai & $n g a n a-y i$ & aux-pres, be-pres \\
\hline ngani & nganhi & I \\
\hline ngankani & $n g a n k a-n i$ & work-nomin \\
\hline ngaperi & ngapiri & father \\
\hline ngarana & ngara-rna & hear-ptcple \\
\hline ngatata & ngathata & younger sibling \\
\hline ngatjai & nganja-yi & want-pres \\
\hline ngatjalu & ngajalu & dear \\
\hline ngato & ngathu & I erg \\
\hline ngudrai & ngundrra-yi & think-pres \\
\hline ngudru & ngundrra- $\emptyset$ & think-imper \\
\hline ngumu & ngumu & good \\
\hline ngupara & ngupara & first \\
\hline ngurali & ngurrha-li & always-erg \\
\hline nikida & nhingkirda & here \\
\hline nina & nhinha & he-acc \\
\hline nulu & nhulu & he erg \\
\hline nunkangudru & nhungkangundrru & him-ablat \\
\hline nunkani & nhungkarni & his \\
\hline nurejali & nhurrhu-yali & quickly-erg \\
\hline palpa & parlpa & few, some \\
\hline paraja & parrha-ya & aux-past \\
\hline pepa & pipa & paper \\
\hline pirna & pirna & big, very \\
\hline punkai & purnka-yi & grow-pres \\
\hline talara & thalara & rain \\
\hline
\end{tabular}




$\begin{array}{ll}\text { tekananto } & \text { thika-rnanthu } \\ \text { tepe } & \text { thipi } \\ \text { tikala } & \text { thika-lha } \\ \text { tipe } & \text { thipi } \\ \text { wadare } & \text { wardaru } \\ \text { wakaja } & \text { waka-ya } \\ \text { walkarali } & \text { walkarrha-li } \\ \text { warai } & \text { warra-yi } \\ \text { watalu } & \text { wata-rlu } \\ \text { watja } & ? \\ \text { wenta } & \text { wintha } \\ \text { windri } & \text { windrri } \\ \text { wodaru } & \text { wardaru } \\ \text { wolja } & \text { walya } \\ \text { worai } & \text { warra-yi }\end{array}$

return-implDS
alive
return-fut
alive
how
small-dat
sad-erg
aux-pres
not-yet
?
when
only
how
soon
aux-pres

\section{BIBLIOGRAPHY}

Anonymous. Nujanujarajinkiniexa - Dieri Jaura jelaribala. Adelaide, 1870. [Possibly written by Koch]

Austin, Peter. A grammar of Diyari, South Australia. Cambridge, 1981.

Berndt, Ronald M. 'A day in the life of a Diyari man before alien contact', Anthropos, 48, 1953:171-201.

Bemdt, R.M. and T. Vogelsang 'The initiation of native doctors, Dieri tribe, South Australia', Records of the South Australian Museum, 6,1938-41:369-80.

Cane, Christine and Niel Gunson. 'Postcards: A source for Aboriginal biography', Aboriginal History, 10, 1986: 171-74.

Fetguson, Charles A. Literacy in a hunting-and-gathering society: The case of Diyari. MS. 1987.

Flierl, J. Christianieli ngujangujara-pepa Dieri jaurani. Adelaide, 1880.

Epistles and Gospels for Sundays and Holy Days of the Christian year. MS. 1884.

Fry, H.K. 'Dieri legends', Folklore, 48, 1937:187-206, 269-87.

Hardy, $\mathrm{O}$. Like a bird on the wing: the story of Luise Homann based on her journal and other sources. Adelaide, 1984.

Howitt, A.W. and O. Siebert. 'Legends of the Dieri and other kindred tribes of Central Australia', Joumal of the Royal Anthropological Institute, 34, 1904:102-128.

Jones, Philip and Peter Sutton. Art and land: Aboriginal sculptures of the Lake Eyre region. Adelaide, 1986.

Proeve, E.H. and H.F.W. Proeve. $A$ work of love and sacrifice: the story of the mission among the Dieri tribe at Cooper's Creek. Adelaide, 1945.

Reuther, J.G. The Diari Translated by P.A. Scherer. Canberra, 1981.

Reuther, J.G. and C. Strehlow. Testamenta Marra. Jesuni Christuni Ngantjani jaura ninaia Karitjamalkana wonti Dieri Jaurani. Tanunda, 1897.

Riedel, W. Ngujangujarra Pepa Diari Talini. MS. [1914?]

Schoknecht, Carl. A dictionary: Dieri-English and English-Dieri. English translation 1947 from unpublished typescript, 1871-73.

Siebert, O. 'Sagen und Sitten der Dieri und Nachbar Stamme in central Australien', Globus, 97, 1900: 44-50, 53-9. 


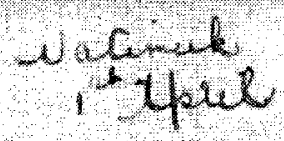

1) eat Nonce

Alany thanhs trdud for you niee (ther gan zerting

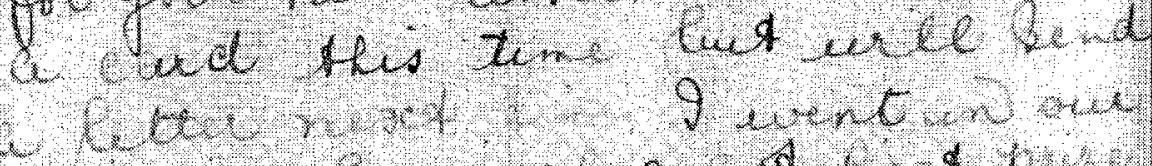

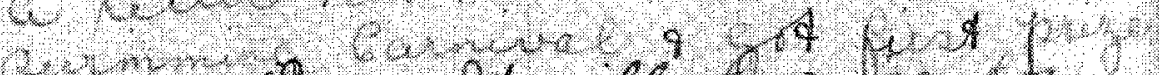

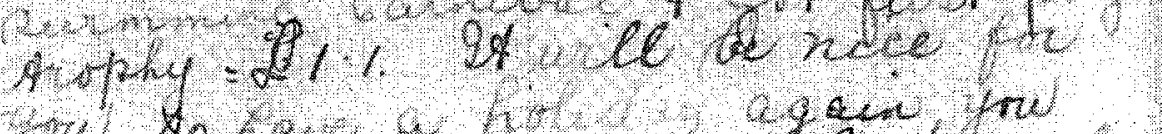

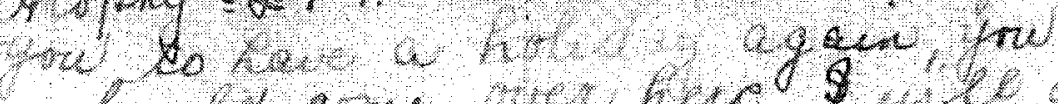

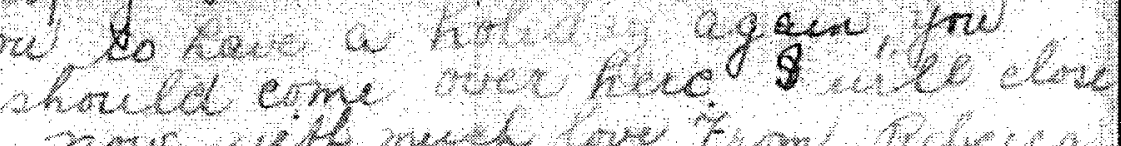

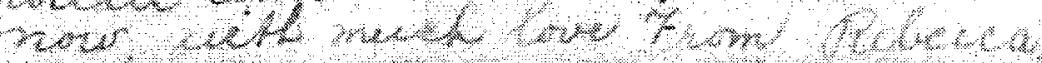

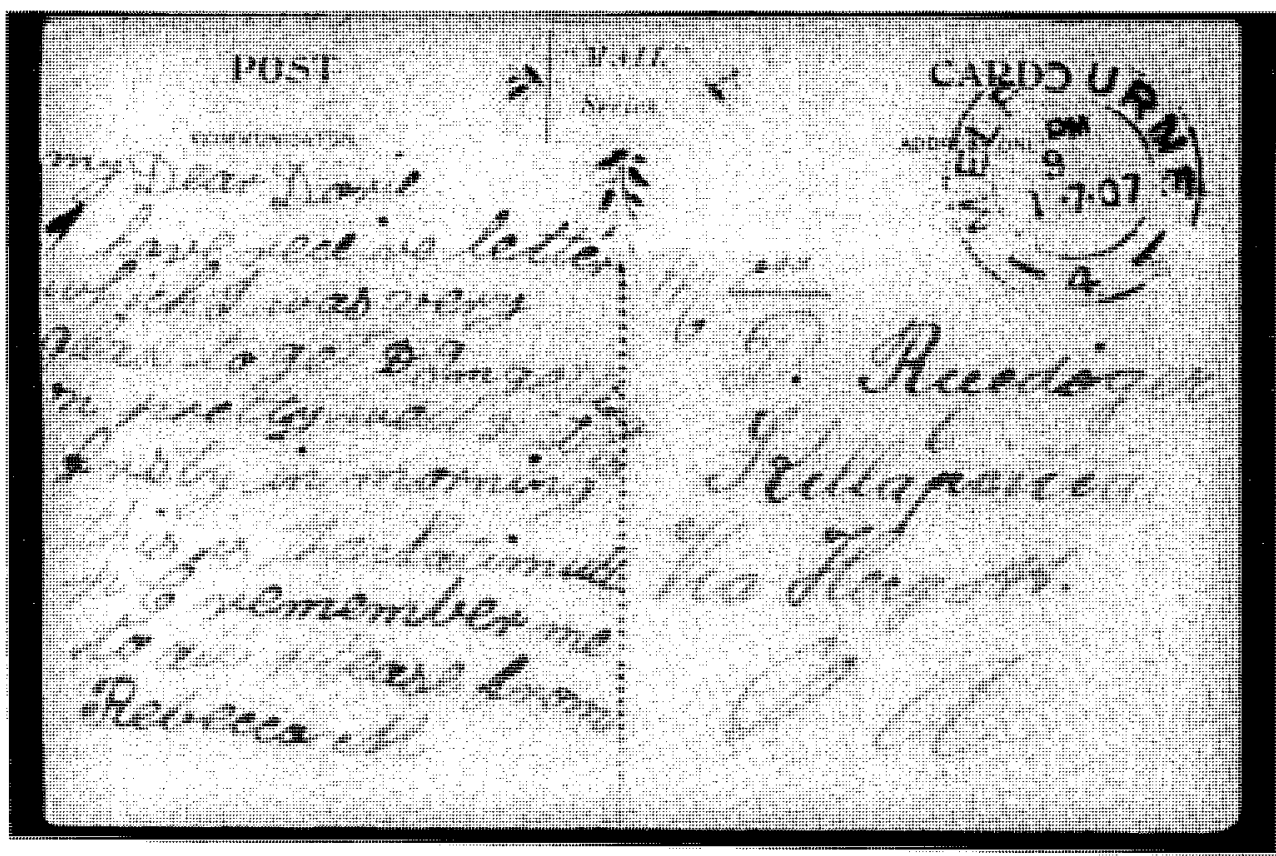

Post cards from Rebecca Maltilina to Dorothea Ruediger 

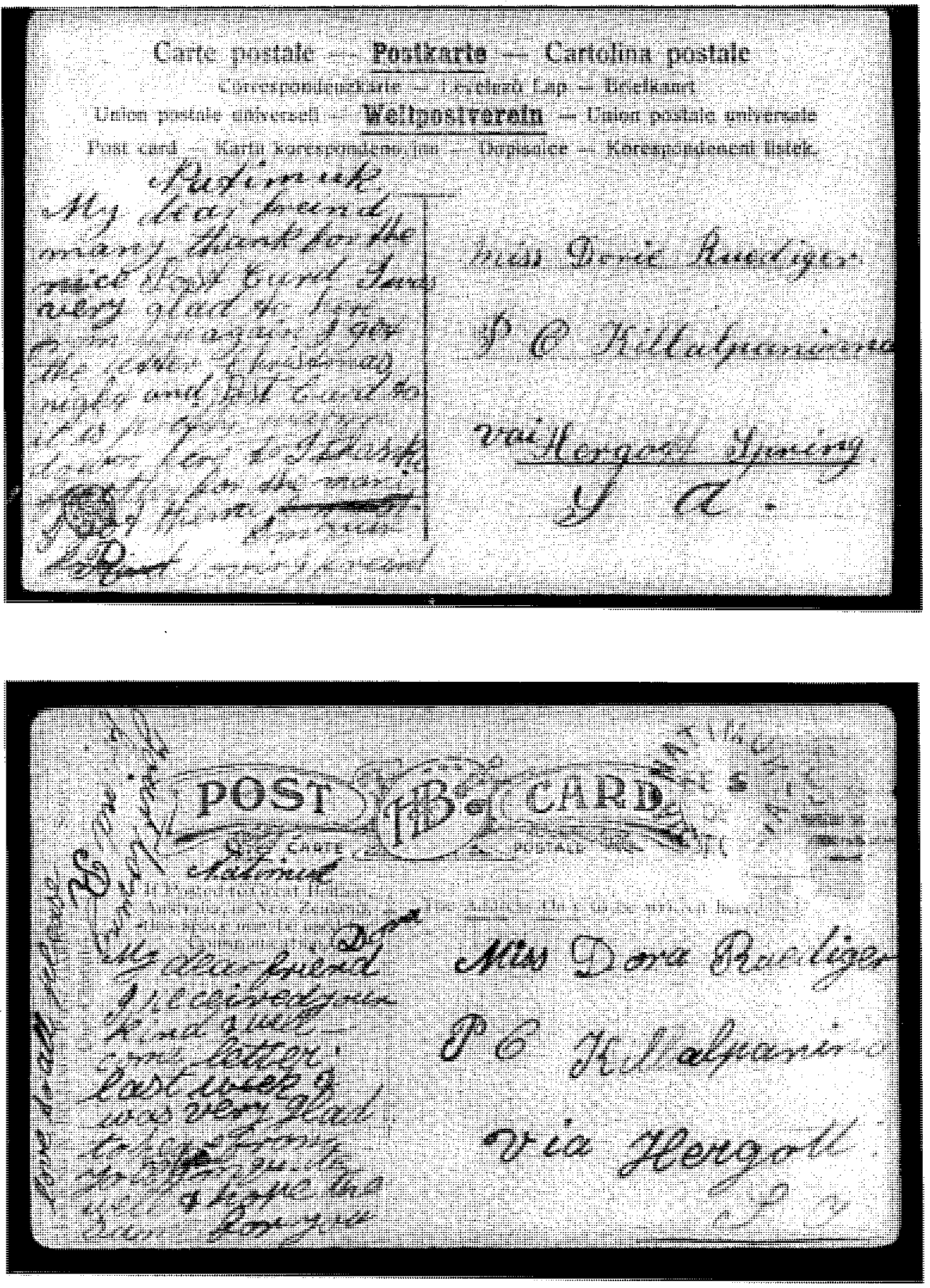

Post cards from Rebecca Maltilina to Dorothea Ruediger 